\title{
Editor's introduction: the art crime prism
}

\author{
Blythe Bowman Proulx
}

Published online: 13 July 2011

(C) Springer Science+Business Media B.V. 2011

For most people, the term art crime invariably brings to mind images of daring museum break-ins, the theft of million-dollar paintings, and the stylish, sexy thieves who mastermind them. In short, most people's imaginations immediately run to something like Pierce Brosnan's character in 1999's Thomas Crown Affair who, bored with his high-powered career in investment banking, entertains himself by stealing his favorite Monet painting from New York City's Metropolitan Museum of Art in an elaborate heist.

Having decidedly caught the public's fancy, art crime has in fact carved out a unique niche within the entertainment industry. Indeed there is no paucity of popular fiction and film ${ }^{1}$ dedicated to the portrayal of sophisticated art heists and the dashing playboy-thieves behind them. And when told that I "study art crime," if one more person responds with "So you're like that Rene Russo detective character in Thomas Crown, then?", I think I'll scream.

In reality, high-value museum thefts are the exception rather than the rule, ${ }^{2}$ and art thieves (unfortunately) rarely look much like Pierce Brosnan. As retired FBI Art Crime Team Special Agent Bob Wittman recounts in his memoir, "art theft is rarely about the love of art or the cleverness of the crime, and the thief is rarely the

\footnotetext{
${ }^{1}$ The following represents but a few examples of recent art crime-themed films: Appointment with Murder, 1948; Topkapi, 1964; How to Steal a Million, 1966; Portrait in Terror, 1966; Framed (TV), 1990; The Object of Beauty (1991); Hudson Hawk (1991); Back in the USSR (1991); Once a Thief (1991); Detonator 2: Night Watch (1995); Avenging Quartet (1993); Two if by Sea (1996); Painted Lady (1997); Carried Away (1998); Red Silk (1999); Starry Night (1999); Thomas Crown Affair (1999); Entrapment (1999); The Score (2001); Artworks (2003); Stark Raving Mad (2992); Tempo (2003); Oceanś Twelve (2004); Art Heist (2004).

${ }^{2}$ Most art thefts take place not in museums but alongside the theft of other items in run-of-the-mill burglaries of private residences [3].
}

The statements and opinions contained in the articles of this volume are solely those of the authors thereof and not of the Journal's Guest Editor, Editor-in-Chief and editorial board, journal staff, or peer reviewers, all of whom disclaim all responsibility for and/or injury to persons or property resulting from any opinions, recommendations, or statements contained in this volume.

B. B. Proulx $(\bowtie)$

Virginia Commonwealth University, Richmond, VA, USA

e-mail: bbproulx@vcu.edu 
Hollywood caricature... The art thieves I met in my career ran the gamut- rich, poor, smart, foolish, attractive, grotesque. Yet nearly all of them had one thing in common: brute greed. They stole for money, not beauty" (2010: 15). Art crime includes a much broader spectrum of criminally punishable conduct ${ }^{3}$ including but not limited to art thefts, confiscations, and smuggling, art insurance and tax fraud, art forgery and fakery, art vandalism and iconoclasm, theft and illicit export of antiquities and other archaeological resources (see Durney \& Proulx, this volume). While these artrelated crimes overlap in significant ways- namely, in terms of both market function and motivation- each crime involving a work of art (or, more broadly, an object of cultural significance) represents a unique phenomenon far removed from the stereotypical Thomas Crown.

In attempting to define crime, Henry and Lanier [1] conceptualize crime as a prism:

"We use the term prism not only because of its visual appearance, but also because, just as a prism is used to analyze a continuous spectrum, so in our case it is used to analyze the spectrum of dimensions that constitute 'crime'. Furthermore, light is refracted in a prism to reveal various colors; likewise, through our crime prism, people may view the same criminal act in different contextual terms depending on their prior experiences, socialization, and worldview" (p. 229).

Like Henry \& Lanier's crime generally, art crime is also multifaceted, multidimensional, value-laden concept which on its face does not reflect the spectrum of conduct it in fact encompasses. Art crime is similarly a prism. This volume attempts to shed light on the prism of art crime by bringing together a broad variety of scholars and expertise. Durney \& Proulx begin the issue with an overview of a variety of different art crimes. Next, Simon Mackenzie employs a white-collar crime perspective on the antiquities market, focusing on the transaction crimes of dealers in illicit cultural objects as "crimes of the powerful." Allison Futterman provides an insightful review of the new memoir (as referenced above), Priceless: How I Went Undercover to Rescue the World's Stolen Treasure (2010), by Bob Wittman and John Shiffman [4]. Next, Christine Alder, Duncan Chappell, and Kenneth Polk examine issues of authenticity and fraud in the Australian Aboriginal art market. Avi Brisman reviews the book, Graffiti Lives: Beyond the Tag in New York's Urban Underground (2009), by Gregory J. Snyder [2]. Next, through an analysis of Sotheby's auction catalogues, Tess Davis examines the supply and demand of illicitly-obtained Cambodian antiquities. Finally, Jennifer Goddard considers illegal digging and archaeological site looting in the Four Corners region of the United States and the effects of recent federal raids conducted in the region which aimed to curb the illicit activity. Together, these papers better illuminate the prism of art crime, and each work represents an important contribution to the growing body of art crime scholarship.

\footnotetext{
${ }^{3}$ It should be noted that not all such conduct is in fact criminally punishable. Some cases are instead handled as civil actions, where plaintiffs seek the return of stolen property or other damages by means of civil proceedings like forfeiture (Hoffman, 2006).
} 
Acknowledgements I want to express my heartfelt gratitude to each and every one of my authors and reviewers who worked tirelessly on the papers in this special issue. I am honored to have colleagues like you. Warm thanks also to Nikos Passas, Anamika Twyman-Ghoshal, and Jennifer Ross for their unwavering support and editorial stewardship. Thanks also to my Wilder School colleagues at VCU for their encouragement and guidance (GO RAMS!). Lastly, much love to Brent Proulx, Alan \& Lynn Bowman, Zoë, and Andy for their steadfast support, patience, and faith.

\section{References}

1. Henry, S., \& Lanier, M. (2001). The prism of crime: toward an integrated definition of crime. In S. Henry \& M. Lanier (Eds.), What is crime. Lanham: Rowman \& Littlefield Publishers.

2. Snyder, G. (2009). Graffiti lives: Beyond the tag in New Yorks urban underground. New York: New York University Press.

3. Tijhuis, E. (2006). Transnational crime and the interface between legal and illegal factors: The case of the illicit art and antiquities trade. Nijmegen: Wolf Legal Publishers.

4. Wittman, R., \& Shiffman, J. (2010). Priceless: How $i$ went undercover to rescue the worlds stolen treasure. New York: Crown Publishing. 